\title{
Association between TERT gene polymorphisms and acute myeloid leukemia susceptibility in a Chinese population: a case- control study
}

\author{
Yong Tong ${ }^{1}$, Yinzhou Xiang ${ }^{2}$, Bao Li ${ }^{3}$, Shijie Bao ${ }^{1}$, Ying Zhou' ${ }^{1}$, Wen Yuan ${ }^{1}$, Yu Ling ${ }^{1}$, Dan Hao ${ }^{1}$, Huamin Zhu \\ and Zhiqiang Sun ${ }^{*}$ (i)
}

\begin{abstract}
Background: The aim of this study was to investigate the association between telomerase reverse transcriptase (TERT) gene polymorphisms and acute myeloid leukemia (AML) susceptibility in a Chinese Han population.

Methods: A total of $102 \mathrm{AML}$ patients and 108 healthy controls were enrolled in this case-control study. TERT gene rs2853669 and rs2736100 polymorphisms were genotyped via polymerase chain reaction-restriction fragment length polymorphism (PCR-RFLP). Chi-square test was applied to compare polymorphism distributions between case and control groups. The strength of the association between TERT gene polymorphisms and AML susceptibility was evaluated utilizing odds ratio (OR) with corresponding 95\% confidence interval (Cl).

Results: CC genotype and C allele of rs 2736100 polymorphism were more frequent in AML patients $(P<0.05)$, and individuals carrying CC genotype showed higher risk of suffering from $A M L(O R=2.632,95 \%$ Cl 1.129-6.133). But for rs2853669 polymorphism, no significant differences were detected in either genotype or allele distributions between groups $(P>0.05)$.
\end{abstract}

Conclusions: This study suggested a positive association between TERT gene rs2736100 polymorphism and AML susceptibility in Chinese Han population.

Keywords: TERT, AML, Susceptibility, PCR-RFLP

\section{Background}

Acute myeloid leukemia (AML) is a malignant disorder of clonal hematopoietic stem cell, and has been considered as the most common acute leukemia affecting adults [1]. AML is characterized by rapid proliferation of leukemic blasts [2]. It can result in abnormal accumulation of immature cells and the suppression of normal

*Correspondence: dsfgdhji@163.com

${ }^{1}$ Department of Hematology, Shenzhen Hospital, Southern Medical University, Shenzhen 518000, Guangdong, China

Full list of author information is available at the end of the article hematopoiesis [3, 4]. Several environmental factors have been identified to be involved in AML development, such as benzene exposure, ionizing radiation, and chemotherapy [5-7]. But not all individuals exposing to the same environmental risk factors will develop AML. Hence, genetic factors are generally accepted to play crucial roles in the pathogenesis of AML.

Telomerase reverse transcriptase (abbreviated to TERT, or hTERT in humans) is a catalytic subunit of telomerase, and together with telomerase RNA component (TERC), constitutes the most important unit of telomerase complex [8]. TERT plays an important role in the

(c) The Author(s) 2020. This article is licensed under a Creative Commons Attribution 4.0 International License, which permits use, sharing, adaptation, distribution and reproduction in any medium or format, as long as you give appropriate credit to the original author(s) and the source, provide a link to the Creative Commons licence, and indicate if changes were made. The images or other third party material in this article are included in the article's Creative Commons licence, unless indicated otherwise in a credit line to the material. If material is not included in the article's Creative Commons licence and your intended use is not permitted by statutory regulation or exceeds the permitted use, you will need to obtain permission directly from the copyright holder. To view a copy of this licence, visit http://creativeco mmons.org/licenses/by/4.0/. The Creative Commons Public Domain Dedication waiver (http://creativecommons.org/publicdomain/ zero/1.0/) applies to the data made available in this article, unless otherwise stated in a credit line to the data. 
maintenance of telomeres, chromosome stability and preventing malignancy [9]. Abnormal activity of telomerase has been reported to be involved in cancer initiation and development, and telomere length shows negative association with cancer incidence and mortality [10].

Human TERT gene is located on chromosome 5p15.33, and several single nucleotide polymorphisms (SNPs) have been identified in this gene. Up to now, numbers of studies have discussed association between TERT gene SNPs and the risks of various cancers, including breast, lung, colorectal, ovarian, prostate, and gastric cancers [11, 12]. Recently, Mosrati et al. [13] have explored the association between TERT polymorphisms and AML susceptibility, focusing on several SNPs, among which only two SNPs (rs2853669 and rs2736100) showed significant association. But genetic association has not been reported in Chinese Han population.

Therefore, a replication was conducted in this paper, and the association of TERT gene rs2853669 and rs2736100 polymorphisms with AML susceptibility was investigated in Chinese Han population.

\section{Methods Subjects}

This case-control study was approved and consented by Ethics committee of Fujian Provincial Hospital, Provincial Clinical Medical College of Fujian Medical University, and protocol number from the Ethic committee was 2019(45). Sample collection was in compliance with the ethnic criteria of national human genome research. Participants involved in this paper all agreed to provide blood samples and receive investigation, and they or their guardians signed informed consent before enrollment. All subjects were Chinese Han population and had no blood relationship with each other.

A total of 210 individuals were enrolled in this study, including $102 \mathrm{AML}$ patients and 108 healthy controls. All cases were first diagnosed with AML at Fujian Provincial Hospital, Provincial Clinical Medical College of Fujian Medical University. AML cases were diagnosed according to World Health Organization criteria, namely increased number of myeloblasts in bone marrow or peripheral blood, and the disease would be confirmed when a 200-cell differential revealed the presence of $20 \%$ or more myeloblasts in a marrow aspirate or in blood [14]. With the following conditions, AML cases would be excluded from the current study: cancer history, blood disorders, diabetes, and connective tissue disease. Another 108 healthy participants were recruited into control group, who visited the same hospital for routine health check-ups during the same period. The individuals in control group were healthy, and had no evidences for family history of blood diseases, cancers, chronic diseases, connective tissue disease, etc. Control group was matched with the case group in age, gender, body mass index (BMI) and life conditions.

\section{DNA extraction}

Blood sample of each participant was collected at diagnosis before treatment initiation. Genomic DNA was isolated from blood samples using TaKaRa Genome DNA Extraction Kit (Dalian Biological Engineering CO., LTD, China) according to manufacturer's instructions. Extracted DNAs were solved in sterile distilled water and stored at $-20^{\circ} \mathrm{C}$ for standby application.

\section{Genotyping}

Polymerase chain reaction-restriction fragment length polymorphism (PCR-RFLP) method was applied for the genotyping of TERT gene rs2853669 and rs2736100 polymorphisms. Primer sequences for the SNPs were designed by Primer Premier 5.0, and synthesized by Sangon Biotech (Shanghai, China) (Table 1). PCR procedures consisted of an initial degeneration at $95{ }^{\circ} \mathrm{C}$ for $5 \mathrm{~min}$, followed by 30 cycles of $94{ }^{\circ} \mathrm{C}$ for $30 \mathrm{~s}$, annealing at $55{ }^{\circ} \mathrm{C}$ for $30 \mathrm{~s}$, and extension at $72{ }^{\circ} \mathrm{C}$ for $30 \mathrm{~s}$, and a final extension at $72{ }^{\circ} \mathrm{C}$ for $7 \mathrm{~min}$. Reaction without DNA sample was employed as negative control.

PCR production was detected through $1.5 \%$ agarose gel electrophoresis. Then each successful PCR product was digested by $10 \mathrm{U}$ restriction endonuclease enzymes (Shanghai Keith Tell biological science and Technology Co., Ltd.). Two enzymes SacI and SfcI were applied for the digestion of PCR productions of rs2853669 and rs2736100 polymorphisms, respectively. Digestion reactions were performed at $37^{\circ} \mathrm{C}$ overnight, and digested fragments were electrophoresed on $3 \%$ agarose gel containing $0.5 \mu \mathrm{g} / \mathrm{mL}$ ethidium bromide, and visualized under UV illumination. Digestion reaction without PCR production was adopted as negative control. In addition, $20 \%$ of amplification results were randomly

\begin{tabular}{lll}
$\begin{array}{l}\text { Table } 1 \text { Primer } \\
\text { and rs2736100 }\end{array}$ & $\begin{array}{c}\text { sequences of } \\
\text { polymorphisms }\end{array}$ \\
\hline SNP & \multicolumn{2}{l}{ Primer sequences } \\
\hline rs2853669 & Sense & 5'-CAGCGCTGCCTGAAACTC-3' \\
& Reverse & 5'-GTCCTGCCCCTCACCTT-3' \\
rs2736100 & Sense & 5'-CCCCACAAGCTAAGCATTAT-3' \\
& Reverse & 5'-GAAGAACCACGCAAAGGAC-3' \\
\end{tabular}


selected and sent for direct sequencing to estimate the accuracy of digestion results.

\section{Statistical analysis}

PASW statistics 18.0 statistical software was applied for data analysis in this paper. Genotype and allele frequencies of TERT gene rs2853669 and rs2736100 polymorphisms were estimated via direct counting and expressed in percentage (\%). Hardy-Weinberg equilibrium (HWE) for each polymorphism in control group was analyzed to assess the quality of the study subjects. Distribution differences of each polymorphism were compared between groups via Chi-square test. Strength of association between TERT gene polymorphisms and AML susceptibility was evaluated adopting odds ratios (OR) with 95\% confidence interval (CI). Two sided $P$-values of less than 0.05 were considered as statistically significant level.

\section{Results}

\section{Baseline characteristics of the study subjects}

There were 102 AML cases including 48 males and 54 females who were aged 33-64, with an average age of $41.23 \pm 3.45$ years. The control group contained 108 healthy individuals, including 52 and 56 females, and they were aged 31-68 years, with an average age of $40.43 \pm 4.07$ years. The control and case groups were matched in age and gender ( $P>0.05$ for both). BMI value was $23.32 \pm 2.29 \mathrm{~kg} / \mathrm{m}^{2}$ in case group and $22.19 \pm 1.96 \mathrm{~kg} /$ $\mathrm{m}^{2}$ in control group was, without significant difference $(P=0.712)$. The distributions of blood white blood count (WBC) were significantly different between case and control groups $(P<0.001)$. Baseline characteristics of case and control groups were summarized in Table 2.

\section{HWE test}

Genotype and allele frequencies of the interested polymorphisms were analyzed through PCR-RFLP method, and the results were in line with sequencing results. All genotypes of TERT gene rs2853669 and rs2736100 SNPs conformed to HWE Law in controls (Table 3, P>0.05), suggesting the representativeness of the study sample.

\section{Association of TERT SNPs with AML}

For rs2853669 polymorphism, GG genotype increased remarkably in case group (20.59\% vs $12.04 \%)$, while AA genotype frequency decreased in cases $(24.51 \%$ vs $33.33 \%)$, but the differences did not reach significant level $(P>0.05)$. G allele frequency also showed a decreasing trend in the case group ( $48.04 \%$ vs $39.35 \%)$, but the difference was not statistically significant $(P>0.05)$. The results suggested that TERT gene rs2853669 polymorphism
Table 2 The detailed information of subjects in cases

\begin{tabular}{|c|c|c|c|}
\hline Characteristics & AML group & Healthy controls & $P$ values \\
\hline Mean age (years) & $41.27 \pm 3.45$ & $40.43 \pm 4.07$ & 0.367 \\
\hline Gender & & & 0.874 \\
\hline Male & $48(47.06)$ & $52(48.15)$ & \\
\hline Female & $54(52.94)$ & $56(51.85)$ & \\
\hline BMI $\left(\mathrm{kg} / \mathrm{m}^{2}\right)$ & $23.32 \pm 2.29$ & $22.19 \pm 1.96$ & 0.712 \\
\hline WBC $\left(\right.$ count $\left.\times 10^{9} / \mathrm{L}\right)$ & & & $<0.001$ \\
\hline$<4$ & $39(38.24)$ & $5(4.63)$ & \\
\hline $4-10$ & $13(12.74)$ & $79(73.15)$ & \\
\hline$>10$ & $50(49.02)$ & $16(14.81)$ & \\
\hline FAB classification & & - & - \\
\hline MO & $2(1.96)$ & & - \\
\hline M1 & $4(3.92)$ & & \\
\hline $\mathrm{M} 2$ & $21(20.59)$ & & \\
\hline M3 & $32(31.37)$ & & \\
\hline M4 & $19(18.63)$ & & \\
\hline M5 & $15(14.71)$ & & \\
\hline M6 & $5(4.90)$ & & \\
\hline M7 & $4(3.92)$ & & \\
\hline Immunophenotype & & - & - \\
\hline T cell type & $21(20.59)$ & & \\
\hline Pre-B cell type & $81(79.41)$ & & \\
\hline Lymphadenopathy & & & - \\
\hline Yes & $20(19.61)$ & $0(0.00)$ & \\
\hline No & $82(80.39)$ & 108 (100.00) & \\
\hline
\end{tabular}

might have no obvious association with AML susceptibility (Table 3).

Significant differences were detected for rs2736100 polymorphism in both genotype and allele distributions between case and control groups. Specifically, CC genotype was more frequent in case group than in controls $(24.51 \%$ vs $14.81 \%)$, while AA genotype frequency was less in case group (18.63\% vs $29.63 \%)$, and the differences reached significant level $(P=0.024)$. Compared with AA genotype carriers, individuals carrying CC genotype showed 2.632 folds higher risk to suffer from AML $(\mathrm{OR}=2.632$, 95\% CI 1.129-6.133). AC genotype showed no obvious distribution differences between case and control groups (56.86\% vs $55.56 \%, P>0.05)$. Besides, rs2736100 $\mathrm{A}$ and $\mathrm{C}$ allele frequencies were $47.06 \%$, $52.94 \%$ in case group and $57.41 \%, 42.59 \%$ in control group, with $\mathrm{C}$ allele significantly increasing in case group $(P=0.034)$. Rs2736100 C allele carriers showed higher risk to suffer from AML $(\mathrm{OR}=1.516$, 95\% CI 1.0322.229). All results suggested that TERT gene rs 2736100 polymorphism was positively associated with AML susceptibility in Chinese Han population, and CC genotype and $\mathrm{C}$ allele were risk factors for AML. 
Table 3 Genotype and allele distributions of TERT gene rs2853669 and rs2736100 polymorphisms in case and control groups

\begin{tabular}{|c|c|c|c|c|c|}
\hline Genotype/allele & $\begin{array}{l}\text { Case } \\
n=102(\%)\end{array}$ & $\begin{array}{l}\text { Control } \\
n=108 \text { (\%) }\end{array}$ & $\chi^{2}$ & $\mathbf{P}$ & OR $(95 \% \mathrm{Cl})$ \\
\hline \multicolumn{6}{|l|}{ rs2853669 } \\
\hline $\mathrm{AA}$ & $25(24.51)$ & $36(33.33)$ & - & - & 1 \\
\hline$A G$ & $56(54.90)$ & $59(54.63)$ & 0.954 & 0.329 & $1.367(0.730-2.561)$ \\
\hline GG & $21(20.59)$ & $13(12.04)$ & 3.775 & 0.052 & $2.326(0.985-5.494)$ \\
\hline A & $106(51.96)$ & $131(60.65)$ & - & - & 1 \\
\hline G & $98(48.04)$ & 85 (39.35) & 3.220 & 0.073 & 1.425 (0.967-2.099) \\
\hline$P^{H W E}$ & & 0.133 & & & \\
\hline \multicolumn{6}{|l|}{ rs2736100 } \\
\hline AA & $19(18.63)$ & $32(29.63)$ & - & - & 1 \\
\hline$A C$ & $58(56.86)$ & $60(55.56)$ & 2.032 & 0.154 & $1.628(0.831-3.190)$ \\
\hline $\mathrm{CC}$ & $25(24.51)$ & $16(14.81)$ & 5.125 & 0.024 & $2.632(1.129-6.133)$ \\
\hline$A$ & $96(47.06)$ & $124(57.41)$ & - & - & 1 \\
\hline$C$ & $108(52.94)$ & $92(42.59)$ & 4.504 & 0.034 & $1.516(1.032-2.229)$ \\
\hline PHWE & & 0.157 & & & \\
\hline
\end{tabular}

\section{Discussion}

AML is a fatal hematopoietic stem cell tumor with poor outcome, inhibiting normal hematopoiesis [15]. For AML patients, early detection and timely treatment can increase survival chances, and cytogenetic and molecular analyses play crucial roles in predicting remission and survival rates [16]. But it is difficult to estimate AML prognosis due to diverse molecular mechanisms of the disease. Therefore, it is necessary to find more effective biomarkers.

Unlimited proliferation is an important characteristic of cancer cells, and the activation of telomerase is a key process to achieve this characteristic in the vast majority of various cancers, including AML $[17,18]$. TERT gene encodes a key catalytic subunit of telomerase, and maintains telomere stability. Gene expression disorder always brings about abnormal telomerase activation and further results in unlimited cell proliferation and even malignancies [19]. Considering central role of TERT in oncogenesis, numerous studies have discussed the association between cancer susceptibility and SNPs in TERT, and accumulated evidences have suggested significant association between two sides [20,21].

In the present study, two SNPs (rs2853669 and rs2736100) in TERT gene were analyzed in $102 \mathrm{AML}$ patients and 108 healthy controls, and significant association was detected between rs2736100 polymorphism and AML susceptibility in Chinese Han population. Significantly higher frequency of rs2736100 CC genotype was detected in AML patients, and individuals carrying CC genotype showed 2.632 folds higher risk of AML. We also found higher frequency of rs2736100 C allele in AML case group, suggesting $C$ allele assumed a promoting effect on the onset of AML. Rs2736100 polymorphism is located in the second intron of TERT gene. Its association with cancer susceptibility has been investigated extensively. Recently, a study has suggested that rs2736100 polymorphism regulated TERT expression and telomere length in gastric cancer patients [22]. As reported by previous study, rs 2736100 CC genotype increased the risk of various cancers, such as bladder, lung and pancreas cancer, but decreased testicular cancer risk [23]. Furthermore, Mosrati et al. [13] have suggested that TERT gene rs2736100 polymorphism significantly increased AML risk in Swedish population. In the present study, TERT gene rs2736100 polymorphism showed positive association with the susceptibility to AML in Chinese Han population, which was in accordance with previous evidences. Besides, rs2736100 CC genotype has been reported to be significantly associated with the upregulation of TERT expression through which its oncogenic effect was exerted [24]. But exact mechanism of rs2736100 polymorphism affecting AML susceptibility has not been explored. Rs2853669 polymorphism is located at $-245 \mathrm{bp}$ from TERT ATG site. Several cancers have been associated with rs 2853669 polymorphism, such as breast cancer and lung cancer [25, 26], though relevant results remain inconclusive. Significant association has also been detected between rs 2853669 polymorphism and AML susceptibility in a Swedish population [13], but no significant association was detected in Chinese Han population. The difference might be caused by different genetic backgrounds. 
Several limitations still presented in this paper which needed to be addressed. Firstly, our study conformed to candidate gene approach, and only one gene and two polymorphisms were involved in the study. Secondly, the sample size was relatively small, which may influence statistical power. Thirdly, gene-environment interaction was not evaluated. Besides, the causality between TERT SNPs and AML susceptibility was not certified in this study. In addition, genetic interactions between different SNPs in TERT gene in AML development were not explored. Thus, more studies with enlarged sample sizes are required to check the impact of TERT gene polymorphisms on AML susceptibility.

\section{Conclusions}

In conclusion, positive association was discovered between TERT gene rs2736100 polymorphism and AML susceptibility in Chinese Han population, and CC genotype was confirmed as a risk factor for AML. Although significant association was detected, more researches are needed to verify the results.

\begin{abstract}
Abbreviations
TERT: Telomerase reverse transcriptase; AML: Acute myeloid leukemia; PCRRFLP: Polymerase chain reaction-restriction fragment length polymorphism; OR: Odds ratio; Cl: Confidence interval; AML: Acute myeloid leukemia; TERC: Telomerase RNA component; SNPs: Single nucleotide polymorphisms; BMI: Body mass index.
\end{abstract}

\section{Acknowledgements}

Not applicable.

\section{Authors' contributions}

$Y T, Y X, B L, S B, Y Z$ design of the work; $W Y, Y L, D H, H Z$, ZS the acquisition, analysis; $Y T, Y X, B L$ interpretation of data; $S B, Y Z$ the creation of new software used in the work; $W Y, Y L$ have drafted the work or substantively revised it. All authors read and approved the final manuscript.

\section{Funding}

Not applicable.

\section{Availability of data and materials}

The datasets used and/or analyzed during the current study are available from the corresponding author on reasonable request.

\section{Ethics approval and consent to participate}

This study was supported by the Ethics Committee of Shenzhen Hospital, Southern Medical University and also has been carried out in accordance with the World Medical Association Declaration of Helsinki.The subjects had been informed the objective. Certainly, written consents were signed by every subject in this study.

\section{Consent for publication}

We obtaining permission from participants to publish their data.

\section{Competing interests}

The authors declare that they have no competing interests.

\section{Author details}

${ }^{1}$ Department of Hematology, Shenzhen Hospital, Southern Medical University, Shenzhen 518000, Guangdong, China. ${ }^{2}$ Department of Otolaryngology,
China Three Gorges University People's Hospital, Yichang 443000, Hubei, China. ${ }^{3}$ Department of Hematopathology, The University of Hong KongShenzhen Hospital, Shenzhen 518000, Guangdong, China.

Received: 2 April 2020 Accepted: 9 June 2020

Published online: 16 July 2020

\section{References}

1. Mandegary A, Rostami S, Alimoghaddam K, Ghavamzadeh A, Ghahremani MH. Gluthatione-S-transferase T1-null genotype predisposes adults to acute promyelocytic leukemia; a case-control study. Asian Pac J Cancer Prev APJCP. 2011;12(5):1279-82.

2. Zaitseva L, Murray MY, Shafat MS, Lawes MJ, MacEwan DJ, Bowles KM, Rushworth SA. Ibrutinib inhibits SDF1/CXCR4 mediated migration in AML. Oncotarget. 2014;5(20):9930-8.

3. Khasawneh MK, Abdel-Wahab O. Recent discoveries in molecular characterization of acute myeloid leukemia. Curr Hematol Malig Rep. 2014;9(2):93-9.

4. Foran JM. New prognostic markers in acute myeloid leukemia: perspective from the clinic. Hematol Am Soc Hematol Educ Program. 2010;2010:47-55.

5. Ferrara F, Schiffer CA. Acute myeloid leukaemia in adults. Lancet. 2013;381(9865):484-95

6. O'Donnell MR, Tallman MS, Abboud CN, Altman JK, Appelbaum FR, Arber DA, Attar E, Borate U, Coutre SE, Damon LE, et al. Acute myeloid leukemia, version 2.2013. J Natl Compr Cancer Netw JNCCN. 2013;11(9):1047-55.

7. Fircanis S, Merriam P, Khan N, Castillo JJ. The relation between cigarette smoking and risk of acute myeloid leukemia: an updated meta-analysis of epidemiological studies. Am J Hematol. 2014;89(8):E125-32.

8. Scarabino D, Broggio E, Gambina G, Pelliccia F, Corbo RM. Common variants of human TERT and TERC genes and susceptibility to sporadic Alzheimers disease. Exp Gerontol. 2017;88:19-24.

9. Ding D, Zhou J, Wang M, Cong YS. Implications of telomere-independent activities of telomerase reverse transcriptase in human cancer. FEBS J. 2013;280(14):3205-11.

10. Willeit P, Willeit J, Mayr A, Weger S, Oberhollenzer F, Brandstatter A, Kronenberg F, Kiechl S. Telomere length and risk of incident cancer and cancer mortality. JAMA. 2010;304(1):69-75.

11. Zhang C, Doherty JA, Burgess S, Hung RJ, Lindstrom S, Kraft P, Gong J, Amos Cl, Sellers TA, Monteiro AN, et al. Genetic determinants of telomere length and risk of common cancers: a Mendelian randomization study. Hum Mol Genet. 2015;24(18):5356-66.

12. Liu T, Yuan X, Xu D. Cancer-specific telomerase reverse transcriptase (TERT) promoter mutations: biological and clinical implications. Genes. 2016;7(7):38.

13. Mosrati MA, Willander K, Falk IJ, Hermanson M, Hoglund M, Stockelberg D, Wei Y, Lotfi K, Soderkvist P. Association between TERT promoter polymorphisms and acute myeloid leukemia risk and prognosis. Oncotarget. 2015:6(28):25109-20.

14. Vardiman JW, Harris NL, Brunning RD. The World Health Organization (WHO) classification of the myeloid neoplasms. Blood. 2002;100(7):2292-302.

15. Kavanagh S, Murphy T, Law A, Yehudai D, Ho JM, Chan S, Schimmer AD. Emerging therapies for acute myeloid leukemia: translating biology into the clinic. JCI Insight. 2017. https://doi.org/10.1172/jci.insight.95679.

16. Godley LA, Cunningham J, Dolan ME, Huang RS, Gurbuxani S, McNerney ME, Larson RA, Leong $H$, Lussier $Y$, Onel $\mathrm{K}$, et al. An integrated genomic approach to the assessment and treatment of acute myeloid leukemia. Semin Oncol. 2011;38(2):215-24.

17. Fonseka LN, Tirado CA. Telomerase in acute myeloid leukemia: a molecular update on diagnosis, prognosis, and treatment. J Assoc Genet Technol. 2016:42(3):105-10

18. Calvello C, Rocca B, Klersy C, Zappatore R, Giardini I, Dambruoso I, Pasi F, Caresana M, Zappasodi P, Nano R, et al. Alternative splicing of hTERT: a further mechanism for the control of active hTERT in acute myeloid leukemia. Leuk Lymphoma. 2018;59(3):702-9.

19. Shay JW. Role of telomeres and telomerase in aging and cancer. Cancer Discov. 2016:6(6):584-93. 
20. Huang FW, Hodis E, Xu MJ, Kryukov GV, Chin L, Garraway LA. Highly recurrent TERT promoter mutations in human melanoma. Science. 2013;339(6122):957-9.

21. Bojesen SE, Pooley KA, Johnatty SE, Beesley J, Michailidou K, Tyrer JP Edwards SL, Pickett HA, Shen HC, Smart CE et al. Multiple independent variants at the TERT locus are associated with telomere length and risks of breast and ovarian cancer. Nat Genet. 2013; 45(4):371-384, 384e371-372.

22. Choi BJ, Yoon JH, Kim O, Choi WS, Nam SW, Lee JY, Park WS. Influence of the hTERT rs2736100 polymorphism on telomere length in gastric cancer. World J Gastroenterol. 2015;21(31):9328-36.

23. Mocellin S, Verdi D, Pooley KA, Landi MT, Egan KM, Baird DM, Prescott J, De Vivo I, Nitti D. Telomerase reverse transcriptase locus polymorphisms and cancer risk: a field synopsis and meta-analysis. J Natl Cancer Inst. 2012;104(11):840-54.

24. Wei R, Cao L, Pu H, Wang H, Zheng Y, Niu X, Weng X, Zhang H, Favus $M$, Zhang $L$, et al. TERT polymorphism rs2736100-c is associated with
EGFR mutation-positive non-small cell lung cancer. Clin Cancer Res. 2015;21(22):5173-80

25. Savage SA, Chanock SJ, Lissowska J, Brinton LA, Richesson D, Peplonska B, Bardin-Mikolajczak A, Zatonski W, Szeszenia-Dabrowska N, Garcia-Closas M. Genetic variation in five genes important in telomere biology and risk for breast cancer. Br J Cancer. 2007;97(6):832-6.

26. Zhong R, Liu L, Zou L, Zhu Y, Chen W, Zhu B, Shen N, Rui R, Long L, Ke J, et al. Genetic variations in TERT-CLPTM1L locus are associated with risk of lung cancer in Chinese population. Mol Carcinog. 2013;52(Suppl 1):E118-26.

\section{Publisher's Note}

Springer Nature remains neutral with regard to jurisdictional claims in published maps and institutional affiliations.
Ready to submit your research? Choose BMC and benefit from:

- fast, convenient online submission

- thorough peer review by experienced researchers in your field

- rapid publication on acceptance

- support for research data, including large and complex data types

- gold Open Access which fosters wider collaboration and increased citations

- maximum visibility for your research: over $100 \mathrm{M}$ website views per year

At BMC, research is always in progress.

Learn more biomedcentral.com/submissions 